\title{
PRODUCTION OF NATURAL RUBBER GRAFTED STYRENE COPOLYMER LATEX AS WATER BASE COATINGS
}

\author{
Marga Utama ${ }^{1}$ and Koentjahja Widjaja ${ }^{2}$ \\ 1. Center for The Appllication of Isotopes and Radiation Technology, National Nuclear Energy Agency \\ (PATIR-BATAN) Jl. Cinere Pasar Jumat P.O.Box. 2 JKSKL, Jakarta 12070. Telp.(021) 7691907. \\ 2. PT. Jaya Karya Utama, Jl. Let. Jen. S. Parman Kav. 107, Jakarta 11440.
}

\begin{abstract}
PRODUCTION OF NATURAL RUBBER GRAFTED STYRENE COPOLYMER LATEX AS WATER BASE COATINGS. Twelve kinds formulation of natural rubber grafted copolymer styrene (NR-g-S) prepared by gamma radiation copolymerization technique has been carried out. The characteristic of NR-g-S and its water base coating such as molecular structure, particle size, and the properties of latex and its film were evaluated. The results showed that the NR-g-S latex as a water base coating has low viscosity, height strength, good grease resistance, good flexibility, good aging and corrosion resistance on concrete cement and metal. The average particle size is between $270-300 \mathrm{~nm}$, and the bonding between poly-isoprene of NRL and styrene molecules were grafted copolymer.
\end{abstract}

Keywords: coating, water based, latex

\section{INTRODUCTION}

Water base coatings can be divided into three main classes : (a) aqueous dispersion or emulsions, (b) colloidal or water - solubility 4 dispersions, and (c) water reducible. The main differences characteristic among the three classes are the particle size and molecular weight such as : the particles size and molecular weight for emulsions are $>0,1 \mu \mathrm{m}$ and one million, but for solubility dispersions are $22-100 \mathrm{~nm}$ and $20.000-200.000$, and for water reducible less then $20 \mathrm{~nm}$, and $20000-50000$. [1].

The synthetic emulsion water base coating prepared by emulsion polymerization techniques available in the market are: styrene butadiene latex, butyl rubber latex, acrylate latex, butadiene acrylonitrile latex, vinyl acetate latex [2]. One of the drawbacks of that synthetic emulsion water base coating is emission of carcinogenic gas from catalyst such as nitrosamine. Some countries have imposed a restriction on the limit of emission for certain uses.

During the past 40 years ago, graft co-polymerization of natural rubber latex prepared by gamma radiation mainly for basic study related to their morphology, structure, etc. has been reported, but very few have reached industrial importance [3-6].

Two aspects graft co-polymerization of natural rubber latex as an adhesive are successively considered: first a more basic approach, to the behavior of pure, non accelerators vulcanizing agent, and second the process is more environment friendly [7-8]. 
According to the above data, this study is to production NR-g-S as water coatings. The hypotheses of this study is to prove that NR-g-S copolymers produced in pilot scale can be used as an aqueous dispersion or emulsions water base coatings with the quality satisfy the standard requirement.

\section{EXPERIMENTAL}

Material. Natural rubber latex with dry rubber content $60 \%$ obtained from Jalupang Rubber Plantation PTPN VIII Subang, Bandung. Styrene monomer obtained from PT.Gajah Tunggal Group Serang, and PT. Pardic Jaya. Jakarta.

Apparatus. Gamma Latex Irradiator with capacity 1,5 ton of emulsions water base coatings, Visconic Viscometer made in Tokyo Keiki Co. Ltd., and Infrared Spectrophotometer IR 435 Shimadzu.

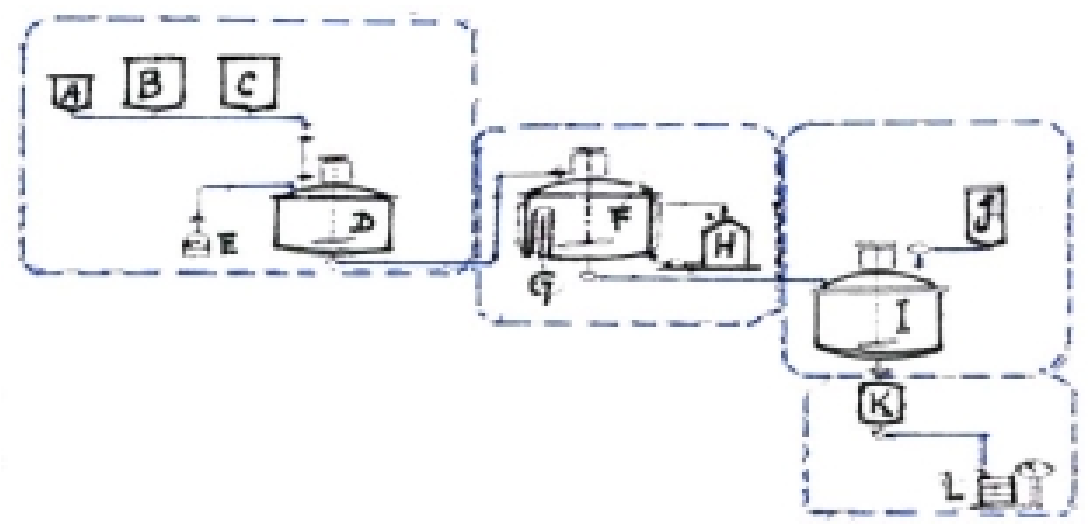

Figure 1. Flow diagram on the production of NR-g-PS prepared by gamma radiation co-polymerization of NRL technique as water base coatings.

Table 1. Three formulation for producing graft copolymer of natural rubber latex styrene prepared by radiation co- polymerization.

\begin{tabular}{|l|c|c|c|}
\hline \multirow{2}{*}{ Chemical } & \multicolumn{3}{|c|}{ Formulation } \\
\cline { 2 - 4 } & I & II & III \\
\hline 40\% Natural Ruber Latex, phr & 100 & 100 & 100 \\
\hline 40\%. Emulsion of styrene,phr. & 25 & 50 & 100 \\
\hline 20\% Surfactant, \%. & 0.5 & 0.75 & 1.0 \\
\hline 20\% solution of KOH, phr. & 1.0 & 1.0 & 1.0 \\
\hline
\end{tabular}


Method. Two steps on the production of water base coatings emulsions prepared by gamma ray radiation co-polymerization technique namely production of NR-g-S, and production of water base coating emulsion are shown on Figure 1, with the details information are as follow:

Production of NR-g-S. Three type formulations of NR-g-S produced in this experiment (Table 1) with the procedure are as follow: Natural rubber latex with total solid content $60 \%$ after dilution to $40 \%$ from drum (A) introduces to the mixture vessel (D) by pump (E). The NR latex was mixed with $0.2 \mathrm{phr}$ of $20 \%$ solution of $\mathrm{KOH}$ and $50 \%$ styrene emulsion from vessel (B) and (C) with concnetration of styrene 25, 50, $100 \mathrm{phr}$. After completely, the mixtures were pumped into the reaction vessel $(\mathrm{F})$ competed with cooling system $(\mathrm{H})$, then irradiated by gamma ray $(\mathrm{G})$ with variation irradiation dose of 15,30 , and $45 \mathrm{kGy}$. After irradiation the NRL-g-S was introduce into the mixing tank (I).

Production of emulsions water base coating. The NRL-g-S latex from mixing tank (I) is mixed by the $1 \%$ solution of $\mathrm{KOH}$ from tank (J) and $10 \%$ or $20 \%$ of talk powder. During addition of $\mathrm{KOH}$ and talc the micture should be stirred until the emulsion was homogeneous, then poured into the drum (L) through the filter (K).

Characterization of the NRL copolymer and it water base coating. The procedure for evaluation the character of NR-g-S and its water base coating such as molecular structure, particle size, properties of NR-g-S latex, and its water base coating were carried out according to the reference 9-11.

\section{RESULT AND DISCUSSION}

Industrial paints can be divided into several groups, depending on the end-uses such as application for finishes, automotive finishes, coil coating, coating for metal container, marine coating, air craft finishes etc. The detail information for the production of NRL-g-S latex prepared by gamma radiation co-polymerization of styrene into natural rubber latex, its emulsions water base coating, and its quality are as follows.

\section{Production of NRL-g-S.}

Radiation grafting of monomer into natural rubber can be carried out in a dry state and in an aqueous dispersion or emulsion. Radiation grafting in an aqueous dispersion or emulsion such in the latex form, has several advantages than in dry state, with the reason as follows:

1. Homogeneous distribution of monomer in rubber and homogeneous irradiation dose can be obtained easily.

2. Grafting reaction rate can be expected to be higher than that in dry state due to the influence of the free radical generated in water phase which diffuse to polymer particles. 
Based on these advantages, this trial production is concentrated on the radiation graft-co-polymerization monomers into NRL form, where the NR particles are as the seed particles, and the monomer emulsion as the monomer droplets.

There are two possible state which the kinetics of radiation graft copolymerization of monomer into NRL. First state the monomer is limited dissolved in natural rubber particles such as the dissolved normal butyl acrylate in rubber particles maximum only $3 \mathrm{phr}$ (part hundred ratio of rubber) [12]. In this state, the monomer is largely located in the monomer droplets, and the polymerization occurs in the water phase. Second state where monomers is unlimited dissolved in the natural rubber particles such as styrene [13-14]. In this state, the monomer is largely located in natural rubber particle, and only a small amount which is in the monomer droplets or dissolved in water. Based on this kinetics the concentration of styrene in this trial production of NR-g-S latex are 25, 50 and $100 \mathrm{phr}$ (Table 1).

The importance factors for producing graft co-polymerization of NRL by gamma irradiation technique are irradiation dose and concentration of monomers. Table 2 shows the effect of irradiation dose and concentration of monomers on the degree of conversion and polymer loading. The degree of conversion increases with the increase in irradiation dose and the irradiation dose of around $30 \mathrm{kGy}$, the degree of conversion obtained $97 \%$ for NR-g-S.

Table 2. The degree of conversion (C) and the polymer loading (PL) of grafted copolymer of natural rubber latex

\begin{tabular}{|c|c|c|c|c|}
\hline Irradiation & C,\%. & \multicolumn{3}{|c|}{ Number formulation* } \\
\cline { 3 - 5 } dose, kGy & PL,\%. & I & II & III \\
\hline 15 & C,\%. & 52.0 & 53.1 & 52.7 \\
& PL,\%. & 17.2 & 22.9 & 27.5 \\
\hline 30 & C,\%. & 97.0 & 99.5 & 98.4 \\
& PL,\%. & 32.0 & 49.6 & 49.7 \\
\hline 45 & C,\%. & 98.0 & 98.5 & 98.0 \\
& PL,\%. & 32.3 & 42.7 & 49.1 \\
\hline
\end{tabular}

* The composition formulation are shown of Table 1.

It means that the optimum irradiation dose for producing NR-g-S latex is around $30 \mathrm{kGy}$, because by using these irradiation dose the degree of conversion is maximum (97.0-99.5\%). The degree of conversion also depends on the monomer concentration in the latex particles, which is due to the difference in reaction efficient.

\section{Production of emulsions water base coating.}

Paints should have both adhesive and cohesive properties in order to be able to joint two materials which are of identical or different nature. Polymers 
with these intrinsic characteristic are rare, and one must resort to blends. However, cohesion in a two-component system is achieve only by chemical bonds between two macromolecules ${ }^{[1]}$. The graft copolymer of NR-g-S not only chemical bonds between natural rubber and monomers but also chemical bond among monomers, so the advantage of graft copolymers are two structurally different type of polymer chains, such as: rigid polystyrene and rubbery natural rubber are associated in the same molecule.

A typical examples is given by system based on talc particle as the cohesive component, and NR-g-S particle as an adhesive component because this water base emulsions coatings contain talc with the particle size $50-100 \mu \mathrm{m}$ as a seed particle, and the NR-g-S with particle size of around $0,1-3 \mu \mathrm{m}$ (Figure 2), as a tacky agent.
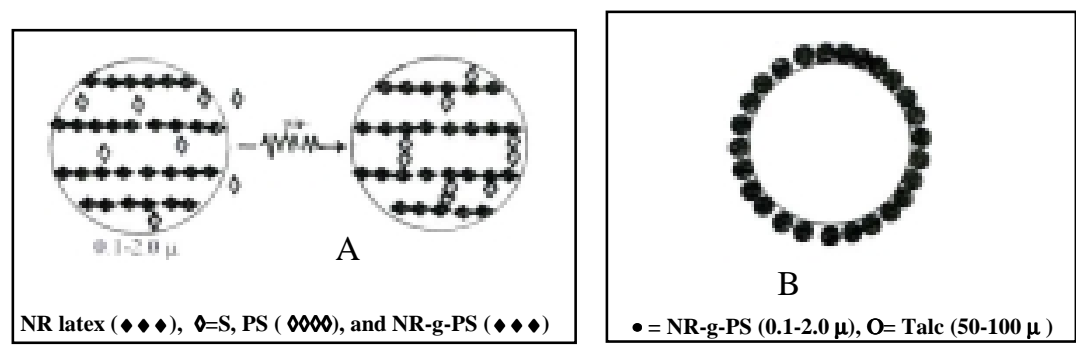

Figure 2. Typical illustration emulsion of NR-g-PS as water base coatings. $\mathrm{A}=$ illustration of radiation co-polymerization, $\mathrm{B}=$ Talc as a seed of particle and NR-g-S as tacky agent.

Table 3. The total solid content (TS) and viscosity(Vis.) of water base coatings with variation composition of NRL-g-PS in talc, and concentration styrene content in NR-g-PS as a tacky agent. The irradiation dose absorbed of NR-g-PS is 30kGy.

\begin{tabular}{|c|c|c|c|c|c|c|}
\hline \multirow{2}{*}{$\begin{array}{c}\text { Composition of } \\
\text { NRL-g-S in talc }\end{array}$} & \multicolumn{3}{|c|}{ Concentration of styrene in NR-g-S, phr. } \\
\cline { 2 - 7 } & $\begin{array}{c}\text { TS, } \\
\% .\end{array}$ & $\begin{array}{c}\text { Vis,c } \\
\text { P }\end{array}$ & $\begin{array}{c}\text { TS, } \\
\% .\end{array}$ & $\begin{array}{c}\text { Vis,c } \\
\text { P. }\end{array}$ & TS,\%. & Vis,cP \\
\hline $100: 0$ & 40 & 52 & 40 & 60 & 40 & 62 \\
\hline $100: 10$ & 45 & 60 & 45 & 67 & 45 & 70 \\
\hline $100: 20$ & 50 & 80 & 50 & 90 & 50 & 95 \\
\hline
\end{tabular}

For industrial purpose it would be helpful to extend the high viscosity of the NR-g-S latex. Just as formulation usually added suitable tacky agent to impact the better viscosity to a given emulsions water base coating. Table 3 shows the adding effect of NR-g-S latex as tacky agent and talc as a seed of 
particle on the viscosity of emulsions water base coating. It indicates that by adding the tacky agent, the viscosity of NR-g-S emulsion coatings increases.

Based on the results research application of the viscosity value coatings in this study, it can be recommended that the viscosity for producing emulsions water base coating is around $90-100 \mathrm{cP}$.

The main additive used for emulsions water base coating are resin (NR-g-S), solvents (water), filler, (talc) and stabilizer $(\mathrm{KOH})$. Usually several different additives are incorporated into the NR grafted copolymers latex. They are chosen to be compatible with one of the phases rather than with both at once. Except for the filler and stabilizers, the solubility parameter of the additive gives a first indication of whether the letter is compatible with the PS, or NR latex.

\section{Quality}

The importance parameters for identify the quality of adhesive are : molecule structure, particle size, properties of latex and its film properties.

\section{Molecule structure}

Two kinds parameters namely infra red and NMR spectra for identification of NR-g-S as water base coating will be discussed in this topic.

Infra Red spectrum. Figure 3 shows the IR spectrum of NR, the mixture of NRL + styrene, and NR-g-S. This spectra prepared by Shimadzu Infra Red Spectrophotometer IR-435. It indicates that the spectrum of NR and the mixture of $\mathrm{NR}+$ styrene are quite the same. It means that the reaction between natural rubber and styrene is not occur, may be styrene was vapor during making a film. The specific finger print spectrum of NR is on the

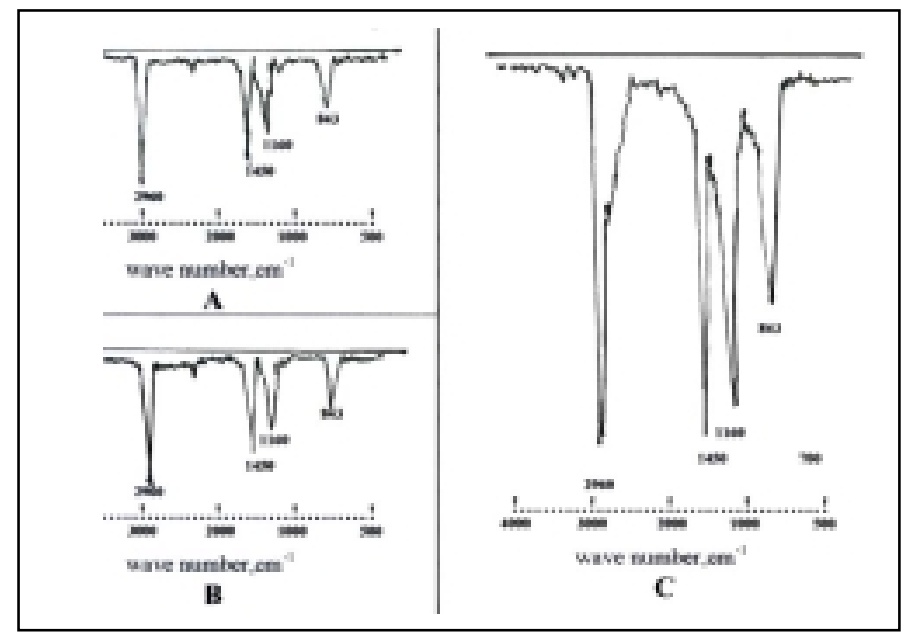

Figure 3. The IR spectra of NRL (A), the mixture of NR and styrene (B), and NR-g-PS film (C). 
wave number 2900, 1450, 1375, and $843 \mathrm{~cm}^{-1}$. The specific finger print spectrum of NR-g-S is on the wave number; 2960, 1660, 1450, 1375, 843, 840 , and $700 \mathrm{~cm}^{-1}$. From this data it can be concluded, that the specific spectra of NR-g-S is not only identified the quality of copolymer, but also can prove the bonding strength between poly-isoprene natural rubber and styrene is chemical bonding which is called graft-copolymer.
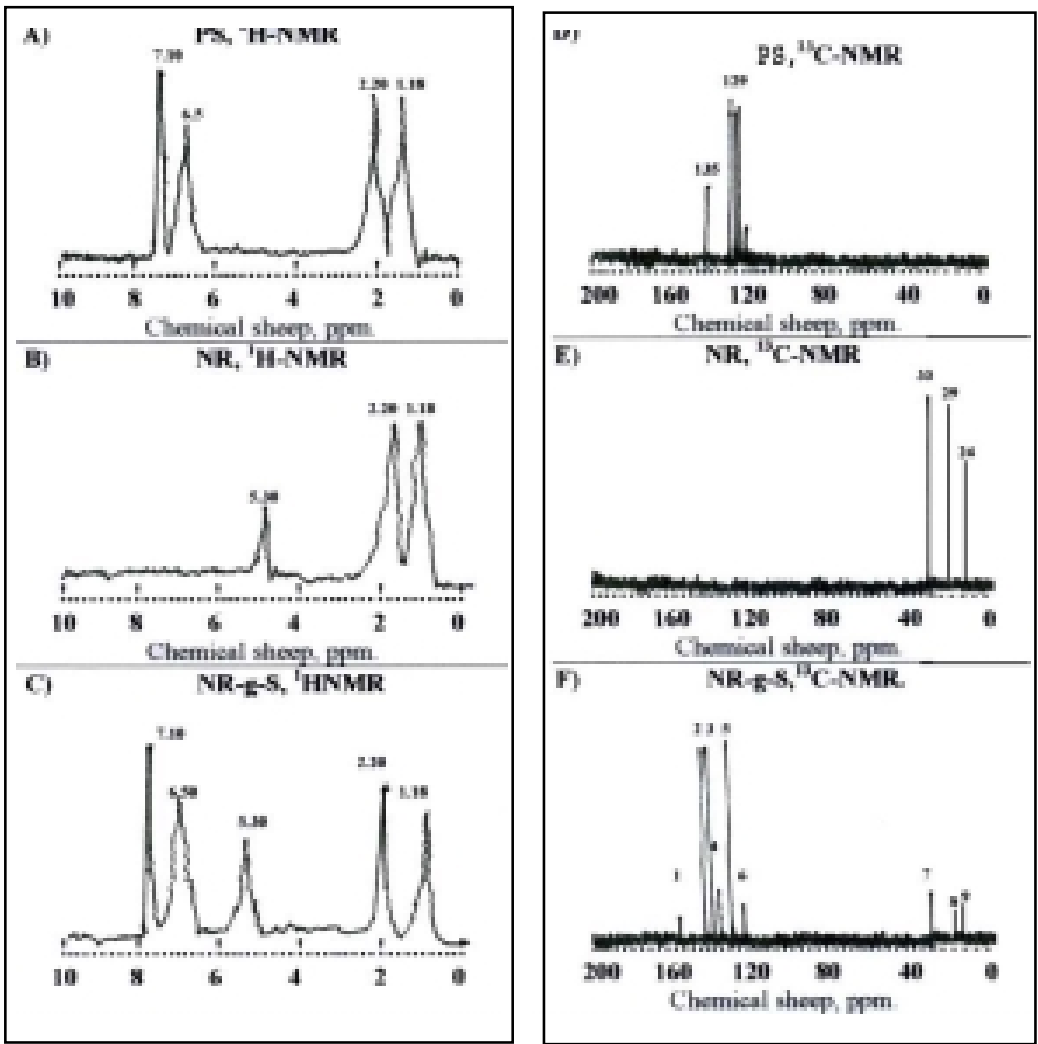

Figure 4. 90-MHz ${ }^{1} \mathrm{H}-\mathrm{NMR}$ of poly-styrene (A), natural rubber (B), NR-g-S (C) and ${ }^{13} \mathrm{C}-\mathrm{NMR}$ of of PS (D), NR (E), and NR-g-S (F).

\section{NMR Spectrum}

Both ${ }^{1} \mathrm{H}-\mathrm{NMR}$ and ${ }^{13} \mathrm{C}-\mathrm{NMR}$ spectra taken at $89 \mathrm{MHz}$ a JEOL FX-90 Q Fourier transform NMR Spectrometer of PS, NR, and NR-g-S is shown on Figure 4. The interpretation of NR and NR-g-S are as follow ${ }^{[15,16]}$; the signal at 6.5 and $7.1 \mathrm{ppm}$ of ${ }^{1} \mathrm{H}-\mathrm{NMR}$ (Figure $4 \mathrm{~A}$ ) are attributed to the phenyl group of PS. The spectra of ${ }^{1} \mathrm{H}-\mathrm{NMR}$ (Figure 4B) shows that the peak observed at $1.8 \mathrm{ppm}$ is attributed the $\mathrm{CH}_{3}$ group of poly-isoprene NR. The signal at 2.2 is attributed to the $-\mathrm{CH}_{2}$, and the signal at 5.3 is attributed to the $=\mathrm{CH}$ of poly-isoprene natural rubber. Figure $4 \mathrm{C}$ Shows that the five spectra of ${ }^{1} \mathrm{H}-\mathrm{NMR}$ shows the combined signal of PS and NR-g-S. 
Further information on the structure is provided by analysis of ${ }^{13} \mathrm{C}$ NMR spectra of the PS, NR, and NR-g-S. Figure 4D-F show the ${ }^{13} \mathrm{CNMR}$ spectra of PS, NR, and NR-g-S. The assignment of the spectra are listed on Table 5. From the table shows that the six signals at 135.4-125.7 are due to the phenyl group of PS. The other three peaks are attributed to the $-\mathrm{CH}_{3}$, $\mathrm{CH}_{2}$, and $=\mathrm{CH}_{2}$ groups of poly-isoprene of NR.

From the results of ${ }^{1} \mathrm{H}-\mathrm{NMR}$ and ${ }^{13} \mathrm{C}-\mathrm{NMR}$ confirm that the dominant content of the film the emulsion are PS, NR, and NR-g-S.

Table 5. ${ }^{13} \mathrm{C}$-NMR chemical shifts (ppm) of the NR-g-PS from Figure 4F.

\begin{tabular}{|c|c|c|c|}
\hline $\begin{array}{l}\text { Covenical shin, } \\
\text { gpm. }\end{array}$ & Indensity & Peak number & Structure \\
\hline 136.366 & 2.2 & 1 & \\
\hline 129.126 & 99.7 & 2 & \\
\hline 128.027 & 97.5 & 3 & \\
\hline 127.373 & 3.7 & 4 & \\
\hline 126.968 & 100.0 & 5 & \\
\hline 125.665 & 3.3 & 6 & \\
\hline 32.699 & 2.7 & 7 & H \\
\hline 26.998 & 37 & 8 & $\begin{array}{c}\mathrm{CH}_{3} \underset{\mathrm{C}}{\mathrm{C}}=\mathrm{Co}_{0} \\
-\mathrm{CH}_{2} \mathrm{CH}_{2}\end{array}$ \\
\hline 23.740 & 3.5 & 9 & ${ }_{-\mathrm{CH}_{2}}^{9 \mathrm{CH}_{3} \mathrm{CH}_{r}}$ \\
\hline
\end{tabular}

\section{Particle size}

There are many ways of "visually" looking at the surface or crosssection of a piece of rubber, with instruments ranging from a simple lens (10 times), through a light microscope (10-400 times), scanning electron microscope (20-300 000 times), to a transmission electron microscope (1000 -1000000 times). Similarly the different elements present may be identified and, within limits, quantified by such techniques as X-ray fluorescence (XRF), electron spectroscopy for chemical analysis (ESCA), and many others, new acronyms for which are appearing continually. Whilst all of these 
have their place, some indeed providing information not obtainable by any other method, the scanning electron microscope (SEM).

The first true SEM was build by Von Ardenne in 1938, but it was not until the mid 1960s that instruments became commercially available and the technique could be considered to have arrived. Most current applications are biomedical, biological or metallurgical and there is still relatively little published on the application of SEM to copolymer of natural rubber analysis[17-18].

The principle of operation is simple, and consists of bombarding the sample with high-energy electron beam, after coating it with a conductive film less then $1 \mathrm{~nm}$ thick to prevent build-up of an electric charge, and monitoring the events which results there from. The two events of interest here are the injection of secondary electron, which are processed to provide a "visual" TV image.

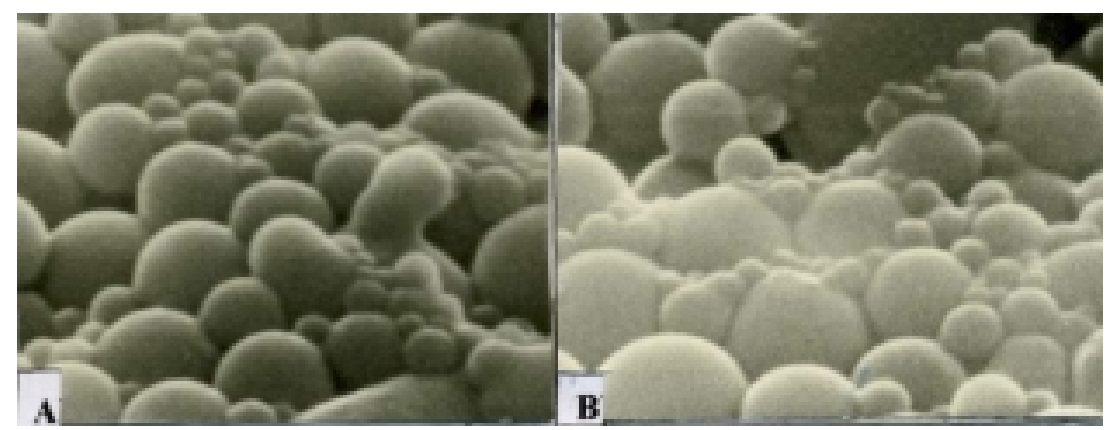

Figure 5. Electron micro-graph of NR (A) and NR-g-PS (B) after magnification 10.000 times.

It is a relatively simple matter to see the distribution latex, if they are hardened before drying with osmium tetroxide $\left(\mathrm{OsO}_{4}\right)$. Figure 5. shows that the difference distribution particle size between natural rubber latex and irradiated natural rubber latex particles is can not seeing, but by using a Nano Seizer apparatus, it was found that the average particles size of natural rubber is around $320 \mathrm{~nm}$, and after radiation grafting of styrene into natural rubber with concentration of styrene $50 \mathrm{phr}$ at $30 \mathrm{kGy}$, the particle average size increases becomes $360 \mathrm{~nm}$. It means that after radiation co-polymerization processing, the rubber particle become swell, due to the cross-linking among poly-isoprene of NRL, grafting of styrene into rubber particles, an homopolymer of poly-styrene. It was also found that natural rubber particles form is an aggregate which consists of a number of particles, and the distribution of the particles diameter are around $0.1-2.0 \mu$. 
Table 5. The properties of latex of NR-g-S latex and its film with different styrene content.

\begin{tabular}{|c|c|c|c|}
\hline \multirow{2}{*}{ Treatment and properties } & \multicolumn{3}{|c|}{ NR-g-S latex } \\
\hline & I & II & III \\
\hline $\begin{array}{l}\text { Treatment } \\
\text { - } \quad \text { Concentration of. Styrene, \%. } \\
\text { - } \quad \text { Irradiation dose, kGy. }\end{array}$ & $\begin{array}{l}33 \\
30 \\
\end{array}$ & $\begin{array}{l}43 \\
30 \\
\end{array}$ & $\begin{array}{l}50 \\
30 \\
\end{array}$ \\
\hline $\begin{array}{l}\text { Latex properties. } \\
\text { - } \quad \mathrm{pH} \\
\text { - } \quad \text { Total solid, } \% . \\
\text { - } \quad \text { Viscosity, cP. }\end{array}$ & $\begin{array}{c}10.8 \\
48,8 \\
16\end{array}$ & $\begin{array}{c}10.7 \\
48.7 \\
17\end{array}$ & $\begin{array}{c}10.5 \\
49.1 \\
19\end{array}$ \\
\hline $\begin{array}{ll}\text { Film properties } \\
\text { - } & \text { Modulus } 300 \%, \mathrm{MPa} . \\
\text { - } & \text { Tensile strength, MPa. } \\
\text { - } & \text { Elongation at break, } \% . \\
\text { - } & \text { Hardness, Shore A. }\end{array}$ & $\begin{array}{c}3.0 \\
12.1 \\
800 \\
60\end{array}$ & $\begin{array}{c}4.1 \\
14.0 \\
750 \\
67\end{array}$ & $\begin{array}{c}5.2 \\
13.0 \\
700 \\
75\end{array}$ \\
\hline $\begin{array}{l}\text { Bonding strength for, } \\
\text { - } \quad \text { Play wood*, } \mathrm{kg} / \mathrm{cm}^{2} . \\
\text { - } \quad \text { Particle board*, } \mathrm{kg} / \mathrm{cm}^{2} . \\
\text { - } \quad \text { Wood Join, } \mathrm{kg} / \mathrm{cm}^{2} . \\
\text { - } \quad \text { Canvas shoes**, N/6mm. } \\
\text { - } \quad \text { Can sealing, } \mathrm{kg} / \mathrm{cm}^{2} .\end{array}$ & $\begin{array}{l}7.8 \\
9.7 \\
4.3 \\
10 \\
5\end{array}$ & $\begin{array}{c}8.9 \\
9.8 \\
4.2 \\
10 \\
6\end{array}$ & $\begin{array}{l}9.7 \\
9.9 \\
3.8 \\
9.8 \\
5\end{array}$ \\
\hline
\end{tabular}

Note: * SNI;01-2704-1992 minimum 7kg/cm², ** SNI; 12-072-1987 minimum value 10/6mm, Formulation : I,II,\&III are shown on Table 1 with irradiation dose $30 \mathrm{kGy}$.

Table 6. The properties of film on the can and concrete after out-door application of can-sealing coating, and concrete cement coatings in $50 \% \mathrm{KOH}$ and $35 \% \mathrm{HCl}$ during six months.

\begin{tabular}{|c|c|c|c|c|c|c|c|c|c|}
\hline \multirow{4}{*}{ Properties } & \multicolumn{9}{|c|}{ Out door application test during 6 months } \\
\hline & \multirow{2}{*}{\multicolumn{3}{|c|}{$\begin{array}{l}\text { Can sealing coating. } \\
\text { On the top of building }\end{array}$}} & \multicolumn{6}{|c|}{ Concrete cement coating } \\
\hline & & & & \multicolumn{3}{|c|}{ In $50 \% \mathrm{KOH}$} & \multicolumn{3}{|c|}{ In $35 \% \mathrm{HCl}$} \\
\hline & I & II & III & I & II & III & I & II & III \\
\hline 1. Color change & $\mathrm{G}$ & $\mathrm{G}$ & $\mathrm{G}$ & $\mathrm{G}$ & $\mathrm{G}$ & $\mathrm{G}$ & $\mathrm{G}$ & $\mathrm{G}$ & $\mathrm{G}$ \\
\hline 2. Checking & $\mathrm{G}$ & $\mathrm{G}$ & $\mathrm{G}$ & G & $\mathrm{G}$ & $\mathrm{G}$ & $\mathrm{G}$ & $\mathrm{G}$ & $\mathrm{G}$ \\
\hline 3. Cracking & G & $\mathrm{G}$ & $\mathbf{F}$ & G & $\mathrm{G}$ & $\mathrm{G}$ & $\mathrm{G}$ & $\mathrm{G}$ & $\mathrm{G}$ \\
\hline 4. Alligatoring & $\mathbf{F}$ & $\mathrm{G}$ & $\mathrm{G}$ & $\mathrm{G}$ & $\mathrm{G}$ & $\mathrm{G}$ & $\mathrm{G}$ & $\mathrm{G}$ & $\mathrm{G}$ \\
\hline 5. Mud cracking & G & G & $\mathbf{F}$ & G & $\mathrm{G}$ & $\mathrm{G}$ & $\mathrm{G}$ & G & $\mathrm{G}$ \\
\hline 6. Wrinkling & $\mathrm{G}$ & $\mathrm{G}$ & $\mathrm{G}$ & $\mathrm{G}$ & $\mathrm{G}$ & $\mathrm{G}$ & $\mathrm{G}$ & $\mathrm{G}$ & $\mathbf{F}$ \\
\hline 7. Blistering & $\mathrm{F}$ & $\mathrm{G}$ & $\mathrm{G}$ & $\mathbf{F}$ & $\mathrm{G}$ & $\mathrm{G}$ & $\mathrm{G}$ & $\mathrm{G}$ & $\mathrm{G}$ \\
\hline 8. Microorganism. & $\mathrm{G}$ & $\mathrm{G}$ & $\mathrm{G}$ & $\mathrm{G}$ & $\mathrm{G}$ & $\mathrm{G}$ & $\mathrm{G}$ & $\mathrm{G}$ & $\mathrm{G}$ \\
\hline 9. Erosion & $\mathrm{G}$ & $\mathrm{G}$ & G & $\mathrm{G}$ & $\mathrm{G}$ & $\mathrm{G}$ & $\mathrm{G}$ & $\mathrm{G}$ & $\mathrm{G}$ \\
\hline 10. Peeling & $\mathrm{G}$ & $\mathrm{G}$ & $\mathrm{G}$ & $\mathrm{G}$ & $\mathrm{G}$ & $\mathrm{G}$ & $\mathrm{G}$ & $\mathrm{G}$ & $\mathrm{G}$ \\
\hline 11. Flaking & G & $\mathrm{G}$ & $\mathrm{G}$ & G & $\mathrm{G}$ & G & $\mathrm{G}$ & G & $\mathrm{G}$ \\
\hline 12. Undercutting & $\mathrm{G}$ & $\mathrm{G}$ & $\mathrm{G}$ & $\mathrm{G}$ & $\mathrm{G}$ & $\mathrm{G}$ & $\mathrm{G}$ & $\mathrm{G}$ & $\mathrm{G}$ \\
\hline 13. Pinhole & $\mathrm{G}$ & $\mathrm{G}$ & $\mathrm{G}$ & $\mathrm{G}$ & $\mathrm{G}$ & $\mathrm{G}$ & $\mathrm{G}$ & $\mathrm{G}$ & $\mathrm{G}$ \\
\hline 14. Holiday. & $\mathrm{G}$ & $\mathrm{G}$ & $\mathrm{G}$ & $\mathrm{G}$ & $\mathrm{G}$ & $\mathrm{G}$ & $\mathrm{G}$ & $\mathrm{G}$ & $\mathrm{G}$ \\
\hline 15. Bleeding. & $\mathrm{G}$ & G & G & G & $\mathrm{G}$ & $\mathrm{G}$ & $\mathrm{G}$ & $\mathrm{G}$ & $\mathrm{G}$ \\
\hline 16. Runs & $\mathrm{G}$ & $\mathrm{G}$ & $\mathrm{G}$ & $\mathrm{G}$ & $\mathrm{G}$ & $\mathrm{G}$ & $\mathrm{G}$ & $\mathrm{G}$ & $\mathrm{G}$ \\
\hline 17. Rusting & $\mathrm{G}$ & $\mathrm{G}$ & $\mathrm{G}$ & $\mathrm{G}$ & $\mathrm{G}$ & $\mathrm{G}$ & $\mathrm{G}$ & $\mathrm{G}$ & $\mathrm{G}$ \\
\hline
\end{tabular}

Formulation NR-g-S Type I, II and III are shown on Table 1 with irradiation dose $30 \mathrm{kGy}$ and contain of talc is $20 \% \mathrm{w} / \mathrm{w} . \mathrm{G}=$ good $=$ no change compared with storage 0 month, $\mathrm{F}=$ fair. 


\section{The properties of latex and its film}

The importance properties for adhesive which has been tested is shown on Table 6. It is indicates that by increasing the polymer loading, the viscosity of latex, modulus, and hardness of film increase, while the maximum tensile strength and adhesive strength for play wood, particle board, and sealing compound were obtained on Type II. Based from these data it can be recommended that NR-g-S Type II can be able for play-wood, particle board adhesive, or can sealing compound.

The effect of out-door application of can coating-application and concrete cement application failures commonly encountered in service on can during 6 months is shown on Table 6. It indicates that the formulation Type II is the best water base coatings, because the properties of film of NR-g-S on can coatings was not change during six months storage out-door application and concrete cement application against solution of $50 \% \mathrm{KOH}$ and $35 \% \mathrm{HCl}$. It means that NR-g-S Type II is a god resistance against base and acid.

Table 7. Technical specification of emulsions water base coating from NR-g-PS latex.

\begin{tabular}{|c|c|c|c|}
\hline Properties & Minimum & Maximum & Average \\
\hline $\begin{array}{l}\text { Latex } \\
\text { 1. Color. } \\
\text { 2. Solid content, \%. } \\
\text { 3. Density, } \mathrm{kg} / \mathrm{l} \\
\text { 3. Viscosity, cP. } \\
\text { 4. Temperature storage, } \\
{ }^{\circ} \mathrm{C} \text {. } \\
\text { 6. Solvent } \\
\text { 7. Solubility in water. } \\
\text { 8. pH }\end{array}$ & $\begin{array}{c}\text { White milk } \\
49 \\
1.0 \\
85 \\
0 \\
\text { water } \\
\text { limited } \\
10.0\end{array}$ & $\begin{array}{c}\text { White milk } \\
51 \\
1.1 \\
95 \\
40 \\
\text { water } \\
\text { limited } \\
10.8\end{array}$ & $\begin{array}{c}\text { White milk } \\
50 \\
1.05 \\
90 \\
20-30 \\
\text { water } \\
\text { limited } \\
10.4\end{array}$ \\
\hline $\begin{array}{l}\text { Film } \\
\text { 1. Density, } \mathrm{kg} / \mathrm{m}^{3} . \\
\text { 2. Modulus } 300 \% \text {, } \\
\text { MPa. } \\
\text { 3. Tensile strength, } \\
\text { MPa. } \\
\text { 4. Elongation at break, } \\
\text { \%. } \\
\text { 5. Hardness, shore A. } \\
\text { 6. IC } \text { I0. } \\
\text { 7. Toxicity } \\
\text { 8. Nitrosamin content } \\
\text { ppb. } \\
\text { 9. Allergy response }\end{array}$ & $\begin{array}{c}0.9 \\
1.0 \\
20 \\
800 \\
40 \\
>10 \\
\text { not toxic } \\
0 \\
\text { not allergy }\end{array}$ & $\begin{array}{c}0.9 \\
1.0 \\
20 \\
800 \\
40 \\
>10 \\
\text { not toxic } \\
0 \\
\text { not allergy }\end{array}$ & $\begin{array}{c}0.9 \\
1.0 \\
20 \\
800 \\
40 \\
>10 \\
\text { not toxic } \\
0 \\
\text { not allergy }\end{array}$ \\
\hline
\end{tabular}




\section{Specification}

The technical specification properties of NR-g-S as water base coatings is shown on Table 7. It can be seen that the coating not only have satisfy the standard requirement, but also free from carcinogenic chemicals (formaldehyde gas emission, and nitrosamine) and protein allergen. The advantages of NR-g-S prepared by radiation technique are more environment friendly.

\section{CONCLUSSION}

From this study it can be concluded that graft copolymer of natural rubber styrene (NRL-g-S) latex prepared by gamma radiation copolymerization technique has been carried out in pilot scale, and can be used for water base coatings.

The quality of NRL-g-S as water base coatings is satisfied for the coating on metal and cement concrete. The bonding strength was not only satisfied with the standard requirement but also free from carcinogenic chemicals such as nitrosamine which can cause cancer.

\section{REFFERENCE}

1. SWARAJ PAOL, Surface Coating; Science and Technology, John Wiley and Sons, New York (1985).

2. BARBARA GORDON, Blue Book Rubber Word Magazine, Lipincott \& Peto Inc., Canada (1995).

3. COCKBAIN E.G., T.D. PENDLE, And D.T.TURNES, J.Polym.Sci XXXIX, 419-426 (1995).

4. WIDMAYER J.M., and G.C.MEYER, Block copolymers adhesive, Developments In Block Copolymers, Edited By I Goodman, Elsevier Appl. Sci. Publisher, London, 161-202 (1985).

5. CAMBELL D.S., Thermoplastic Elastomeric Graft Copolymers, Developments In Block Copolymers, Edited by I Goodman, Elsevier Appl. Sci. Publisher, London, 161-202 (1985).

6. SUNDARDI F., and KADARIJAH, Radiation Grafting Of Methyl Methacrylate On Natural Rubber Latex, J.App. Polym. Sci, Vol 29, 1515-1521 (1984).

7. MARGA UTAMA, 2002, Trial Production of Plywood in factory scale with NR-g-S as an its adhesive, Proc. of The Fourth International Wood Sci. Symp., JSPS, Kyoto, 193-198 (2000). 
8. MARGA UTAMA, SUDIRMAN, and PENNY SETIOWATI, Study on the production of kanvas shoes sdhesive from NR-g-PMMA, Indonesian Journal Of Materials Of Materials Science, Vol 4, No.1, 1-8. (2002).

9. ASTM, Standard Specification For Latex Concentrated, Ammonia Preserved, Creamed, And Centrifuging Latex, ASTM D 412-2005.

10. ASTM, Standard Test Method For Analysis Of Protein In Natural Rubber Latex And Its Product, ASTM D 5712-95.

11. HERWINARNI, and MARGA UTAMA, Identivikasi Nitrosamin Dalam Lateks Alam Pra-Vulkanisasi, Prosidings IPTEK Bahan 04, P3IB-Batan, PUSPITEK Serpong, 65-69 (2004).

12. WANG CUNG LEI, Reduction of residual normal butil acrylate as sensitizer to RVNRL, Proc. The International symposium on RVNRL, MINT, Kuala Lumpur (1996) 252.

13. JOER R FRIED, Polymer Science and Technology, Prontice-Hall International Inc., New Jersey 07632 (1995).

14. BRANDRUP, j., imergut,e.h., Polymer Handbook, sec. Ed., John Willey $\&$ Sons, New York (1995).

15. R.H. BIBLE, Interpretation of NMR spectra, Plenum, New York (1965).

16. W.C.WAKE, B.K.TIDD, M.J.R.LLOADMAN, Analysis of Rubber and Rubber-lika Polymer, third Edition, Applied Science Publishers, London (1983).

17. MARGA UTAMA, F.SUNDARDI, HERWINARNI, MADE SUMARTI, S.ISKANDAR, D.IRAMANI, K.MAKUUCHI, F.YOSHII, Characterization of natural rubber latex from Indonesia, Proc. the International Symposium on RVNRL, edited by Sueo MACHI, JAERIM 69-228, Tokyo, 169-177 (1990).

18. MARGA UTAMA, Diameter distribution of NR-g-MMA, Bulletin Chemical Analysis College, Bogor, 12-18 (1995). 